Journal Club

Editor's Note: These short, critical reviews of recent papers in the Journal, written exclusively by graduate students or postdoctoral fellows, are intended to summarize the important findings of the paper and provide additional insight and commentary. For more information on the format and purpose of the Journal Club, please see http://www.jneurosci.org/misc/ifa_features.shtml.

\title{
Histamine and Orexin in the Control of Arousal, Locomotion, and Motivation
}

\author{
Christian R. Burgess \\ Department of Cell and Systems Biology, University of Toronto, Toronto, Ontario M5S 3G5, Canada \\ Review of Anaclet et al.
}

Histamine and orexin/hypocretin are neurotransmitters that have unique roles in promoting wakefulness, and likely act synergistically to promote and maintain waking behavior. Histamine neurons located in the tuberomammillary nucleus and surrounding regions fire tonically during waking (Steininger et al., 1999), whereas orexin neurons located in the perifornical area fire during waking and phasic periods of rapid eye movement (REM) sleep (Mileykovskiy et al., 2005). These transmitter systems innervate brain regions involved in all aspects of sleepwake regulation, including projections from orexinergic to histaminergic neurons (Siegel, 2009). The generation of knock-out mice lacking either the histidine decarboxylase gene (HDC KO) or the prepro-orexin gene $(\mathrm{Ox} \mathrm{KO})$ has allowed investigators to elucidate the roles these transmitters play in regulating sleep-wake behavior. Mice lacking histamine have increased amounts of REM sleep and evidence of somnolence, as demonstrated by decreased sleep latency in response to behavioral stimuli (Parmentier et al., 2002). In contrast, mice lacking orexin peptides do not exhibit different amounts of sleep-wake states across a $24 \mathrm{~h}$ period; how-

Received Jan. 5, 2010; revised Jan. 20, 2010; accepted Jan. 21, 2010.

I thank Natural Sciences and Engineering Research Council of Canada for PhD funding, as well as Drs. J. H. Peever, T. E. Scammell, and J. M. Siegel for helpful comments.

Correspondence should be addressed to Christian R. Burgess, Department of Cell and Systems Biology, University of Toronto, 25 Harbord Street, Toronto,0ntario M5S3G5, Canada.E-mail: christian.burgess@utoronto.ca. DOI:10.1523/JNEUROSCI.0045-10.2010

Copyright $\odot 2010$ the authors $\quad 0270-6474 / 10 / 302810-02 \$ 15.00 / 0$ ever, they have behavioral state instability (i.e., increased transitions between states) (Mochizuki et al., 2004). In addition to this, Ox KO mice have behavioral arrests that include both non-REM and REM sleep attacks, as well as cataplexy (involuntary loss of muscle tone during waking), a common symptom of narcolepsy (Chemelli et al., 1999; Mochizuki et al., 2004). The distinct roles these transmitters play in promoting specific aspects of wakefulness (i.e., cognition, locomotion, etc.) are not fully understood.

In a recent study published in The Journal of Neuroscience, Anaclet et al. (2009) made use of these knock-out mice to investigate the unique roles histamine and orexin have in promoting the different aspects of wakefulness. The authors first investigate the basic sleep-wake characteristics of Ox KO mice and demonstrate that these mice have normal amounts of sleep and wakefulness [Anaclet et al. (2009), their Fig. 2] despite their behavioral state instability [Anaclet et al. (2009), their Table 1]. The authors then demonstrated that, during spontaneous sleep and waking, EEG characteristics do not differ between $\mathrm{Ox} \mathrm{KO}$ and wild-type mice, a key difference between these mice and HDC KO mice, which show several changes in cortical EEG spectral power compared with wild types [Anaclet et al. (2009), their Fig. 3]. Ox KO mice also exhibit a reduced ability to maintain wakefulness with an environmental change [Anaclet et al. (2009), their Fig. 4]

Perhaps the most important result of the study is the differing responses of HDC
$\mathrm{KO}$ and $\mathrm{Ox} \mathrm{KO}$ mice when placed on a running wheel. HDC KO mice responded similarly to wild types, with an increase in wakefulness and similar amounts of locomotion (i.e., wheel running) [Anaclet et al. (2009), their Fig. 5]. Conversely, Ox KO mice did not respond with the same increased wakefulness and exhibited significantly less locomotion than wild types [Anaclet et al. (2009), their Figs. 6, 7]. Importantly, treatment of $\mathrm{Ox} \mathrm{KO}$ mice with orexin peptides increased wake and locomotion; in addition, in wild-type mice, pretreatment with an orexin antagonist mimicked the results seen in $\mathrm{Ox} \mathrm{KO}$ mice [Anaclet et al. (2009), their Fig. 7]. These results suggest, as the authors note, that orexin contributes to the maintenance of wakefulness by enhancing locomotion. In contrast, histamine appears to be involved in the cognitive aspects of wakefulness. This sets up complementary roles for histamine and orexin in the control of wakefulness and suggests that the excessive sleepiness observed in narcolepsy is not attributable to lack of orexin per se but is attributable to decreased histaminergic transmission as a result of the loss of orexin. This conclusion is supported by recent findings that human narcoleptics have decreased histamine in their CSF (Nishino et al., 2009).

Anaclet et al. (2009) interpret the reduced wheel running of Ox KO mice as an indication that orexin functions to promote arousal through locomotion. There is evidence that orexin is involved in locomotion, including that orexin neurons fire much more during active versus quiet 
waking (Mileykovskiy et al., 2005), CSF orexin levels correlate with movement (Wu et al., 2002), and orexin excites motor neurons directly (Peever et al., 2003).

However, alternative interpretations include that $\mathrm{Ox} \mathrm{KO}$ mice do not run as much as their wild-type littermates because they have excessive sleepiness or that they do not find wheel running as rewarding. In a previous study in which mice were given a choice between wheel running and sleeping, España et al. (2007) showed that Ox KO mice had the same average and maximal running speed as wild-type mice, but the average duration of each running bout, and thus overall running time, was lower in $\mathrm{Ox} \mathrm{KO}$ mice. This could suggest that $\mathrm{Ox} \mathrm{KO}$ mice stop running because they have excessive sleepiness or because they do not find wheel running as rewarding as wild types. There is evidence that wheel running can be rewarding in rodents (Lett et al., 2002). Orexin peptides are also linked with rewarding stimuli: orexin neurons innervate reward centers in the brain and fire in response to specific rewards (Harris et al., 2005). Indeed, Anaclet et al. (2009) demonstrate using c-fos that orexin neurons are active during wheel running in wildtype mice [Anaclet et al. (2009), their Fig. 8]; perhaps the orexin system strengthens the rewarding effect of wheel running, motivating mice to continue. McGregor et al. (2007) demonstrated that Ox KO mice have impaired motivation using a task that is not as dependent on locomotion. They showed that Ox KO mice bar press significantly less for a positive reward, indicating that they could have decreased motivation, whereas they bar press equally to avoid a negative outcome, indicating that impaired locomotion is not the reason for decreased bar pressing with a positive outcome. Furthermore, to address whether an inability to maintain wakefulness contributed to the lack of wheel running in $\mathrm{Ox} \mathrm{KO}$ mice, it would be interesting to alleviate the excessive sleepiness pharmacologically (e.g., with an $\mathrm{H} 3$ histamine receptor inverse agonist) and observe whether these mice run more.

In addition to differences in wheel running, HDC KO and Ox KO mice differ in that $\mathrm{Ox} \mathrm{KO}$ mice show behavioral arrests. Several studies have demonstrated the presence of both sleep attacks and cataplexy in these mice (Mochizuki et al., 2004; España et al., 2007; Clark et al., 2009; Scammell et al., 2009). In contrast, Anaclet et al. (2009) do not report any instances of cataplexy in Ox KO mice, only episodes of "narcolepsy" defined as direct transitions from wake to REM sleep. In- deed, studies have demonstrated not only spontaneous cataplexy in these mice, using EEG, EMG, and videography, but also that specific stimuli can trigger cataplexy, such as wheel running, palatable food, or an open field (Mochizuki et al., 2004; España et al., 2007; Clark et al., 2009; Scammell et al., 2009). In addition, it has been shown that cataplexy and REM sleep are unique states in these mice that can be independently manipulated with specific dopamine receptor modulators (Burgess et al., 2008). Perhaps because of the relatively short duration of cataplexy, infrequent occurrence, and the fact that the authors scored behavior in $30 \mathrm{~s}$ epochs, bouts of cataplexy were missed. Alternatively, the direct entrances to REM sleep mentioned in the manuscript could be cataplexy, as murine cataplexy is defined by immobility and theta-dominant EEG that lasts at least $10 \mathrm{~s}$ and follows wakefulness, which is very similar to the authors' description of direct-onset REM episodes (Scammell et al., 2009).

The evidence for the authors' conclusion that histamine is important for aspects of consciousness and cognitive function is strong, including that HDC $\mathrm{KO}$ mice have impaired cortical activation (Anaclet et al., 2009) and that putative histamine neurons continue to fire during cataplexy in narcoleptic canines (John et al., 2004). As stated previously, the conclusion that reduced histamine transmission could be responsible for some of the excessive daytime sleepiness in narcolepsy is supported by the finding that there are decreased histamine levels in the CSF of human narcoleptics (Nishino et al., 2009). Both the orexinergic and histaminergic systems are necessary for the promotion and maintenance of wakefulness. Determining how these neurotransmitter systems function and interact is critical to the understanding of sleep and wakefulness, and could have clinical significance when treating disorders of hypersomnolence. The study by Anaclet et al. (2009) is a useful start in determining the relative roles that histamine and orexin play in the different aspects of wakefulness. However, additional research is required to elucidate the precise role of orexin in arousal, motivation, and locomotion.

\section{References}

Anaclet C, Parmentier R, Ouk K, Guidon G, Buda C, Sastre JP, Akaoka H, Sergeeva OA, Yanagisawa M, Ohtsu H, Franco P, Haas HL, Lin JS (2009) Orexin/hypocretin and histamine: distinct roles in the control of wakefulness demonstrated using knock-out mouse models. J Neurosci 29:14423-14438.

Burgess CR, Tse G, Peever JH (2008) Dopami- nergic modulation of cataplexy in hypocretinnull mice. Sleep 31:A0014.

Chemelli RM, Willie JT, Sinton CM, Elmquist JK, Scammell T, Lee C, Richardson JA, Williams SC, Xiong Y, Kisanuki Y, Fitch TE, Nakazato M, Hammer RE, Saper CB, Yanagisawa M (1999) Narcolepsy in orexin knockout mice: molecular genetics of sleep regulation. Cell 98:437-451.

Clark EL, Baumann CR, Cano G, Scammell TE, Mochizuki T (2009) Feeding-elicited cataplexy in orexin knockout mice. Neuroscience 161:970-977.

España RA, McCormack SL, Mochizuki T, Scammell TE (2007) Running promotes wakefulness and increases cataplexy in orexin knockout mice. Sleep 30:1417-1425.

Harris GC, Wimmer M, Aston-Jones G (2005) A role for lateral hypothalamic orexin neurons in reward seeking. Nature 437:556-559.

John J, Wu MF, Boehmer LN, Siegel JM (2004) Cataplexy-active neurons in the hypothalamus: implications for the role of histamine in sleep and waking behavior. Neuron 42:619-634.

Lett BT, Grant VL, Koh MT, Flynn G (2002) Prior experience with wheel running produces cross-tolerance to the rewarding effect of morphine. Pharmacol Biochem Behav 72: 101-105.

McGregor R, Wu MF, Boehmer LN, Abordo K, Siegel JM (2007) Reduced motivated behavior in hypocretin knockout mice. Soc Neurosci Abstr 33:97.7.

Mileykovskiy BY, Kiyashchenko LI, Siegel JM (2005) Behavioral correlates of activity in identified hypocretin/orexin neurons. Neuron 46:787-798.

Mochizuki T, Crocker A, McCormack S, Yanagisawa M, Sakurai T, Scammell TE (2004) Behavioral state instability in orexin knock-out mice. J Neurosci 24:6291-6300.

Nishino S, Sakurai E, Nevsimalova S, Yoshida Y, Watanabe T, Yanai K, Mignot E (2009) Decreased CSF histamine in narcolepsy with and without low CSF hypocretin-1 in comparison to healthy controls. Sleep 32:175-180.

Parmentier R, Ohtsu H, Djebbara-Hannas Z, Valatx JL, Watanabe T, Lin JS (2002) Anatomical, physiological, and pharmacological characteristics of histidine decarboxylase knock-out mice: evidence for the role of brain histamine in behavioral and sleep-wake control. J Neurosci 22:7695-7711.

Peever JH, Lai YY, Siegel JM (2003) Excitatory effects of hypocretin-1 (orexin-A) in the trigeminal motor nucleus are reversed by NMDA antagonism. J Neurophysiol 89:2591-2600.

Scammell TE, Willie JT, Guilleminault C, Siegel JM (2009) A consensus definition of cataplexy in mouse models of narcolepsy. Sleep 32:111-116.

Siegel JM (2009) The neurobiology of sleep. Semin Neurol 29:277-296.

Steininger TL, Alam MN, Gong H, Szymusiak R, McGinty D (1999) Sleep-waking discharge of neurons in the posterior lateral hypothalamus of the albino rat. Brain Res 840:138-147.

Wu MF, John J, Maidment N, Lam HA, Siegel JM (2002) Hypocretin release in normal and narcoleptic dogs after food and sleep deprivation, eating, and movement. Am J Physiol Regul Integr Comp Physiol 283:R1079-R1086. 